\title{
Entre memórias e histórias: participação pública no conhecimento histórico
}

\section{Carlos Eduardo Pereira de Oliveira*}

ORCID iD 0000-0003-0156-5460

Universidade do Estado de Santa Catarina, Programa de Pós-Graduação em História, Florianópolis, Brasil

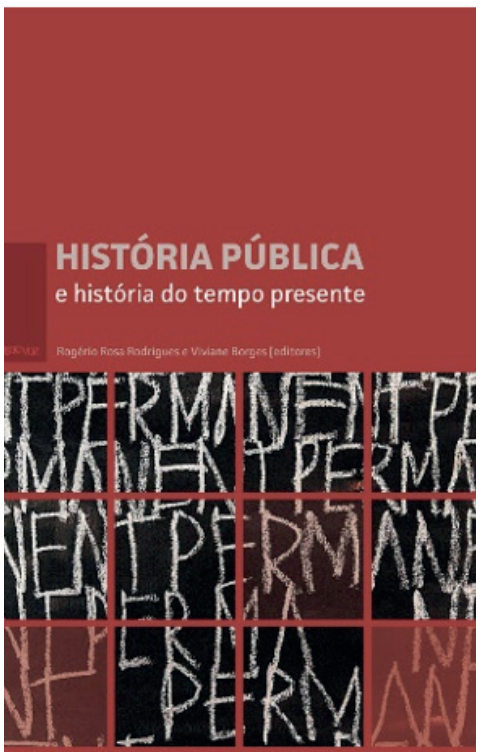

RODRIGUES, Rogério Rosa; BORGES, Viviane

(Org.). História Pública e História do Tempo

Presente. São Paulo: Letra e Voz, 2021.

Doutorando em História pela Universidade do Estado de Santa Catarina (Udesc), com orientação da Profa. Dra. Márcia Ramos de Oliveira.E-mail: kaduoliveira23@gmail.com. 
Observou-se nas últimas décadas um crescimento em estudos que destacam a memória como objeto ou fonte de pesquisas históricas. Pautada principalmente a partir da década de 1980, sua interlocuçáo com a história permitiu intensos debates sobre temáticas caras ao passado presente. A História Oral se estabeleceu como prática no campo, consolidou diferentes vertentes teórico-metodológicas e adensou as discussóes entre memória e história. Conectada pela memória, a área se aproxima da História do Tempo Presente, e em consonância com a História Pública, busca amarrar esses pontos, com foco em produçóes realizadas com (e para) o público.

Essas questóes estão no livro História Pública e História do Tempo Presente, lançado em 2020 pela editora Letra e Voz, com organização de Rogério Rosa Rodrigues e Viviane Borges, docentes na Universidade do Estado de Santa Catarina (Udesc). Seus escritos são marcados pelas interfaces de contato entre esses campos, e desenvolvem pesquisas que abordam a relação entre temporalidades, memória, estratos temporais e o caráter público da história. A obra possui dez capítulos, divididos em artigos e entrevistas, e busca contribuir com diferentes panoramas a partir de linhas teóricas e discussōes que se cruzam. Reunindo 12 autores, o livro nos convoca a pensar sobre os usos do passado, a monumentalização e o fomento de um campo preocupado com as implicaçōes públicas do fazer histórico.

Caroline Bauer, professora da Universidade Federal do Rio Grande do Sul (UFRGS), abre a obra com capítulo que analisa as construções da memória de Castello Branco. Para isso, observa os processos de preservaçáo dos últimos espaços no qual ele esteve antes de sua morte. Investiga também a construção de um mausoléu em Fortaleza (CE), no qual repousam os restos mortais do ditador. Bauer enxerga a proximidade entre presente e passado por meio das ausências, que se consolida através do apagamento da história da ditadura no Brasil. A imagem de Castello Branco é fio condutor dessa discussão, justamente por ser apresentado a partir de "uma narrativa biográfica de exemplaridade".

Viviane Borges discute estratégias de História Pública a partir de temas sensíveis. Em "Para além da beleza e da dor", ela parte da trajetória de três sujeitos em diferentes instituiçóes de controle catarinenses, em exposiçóes organizadas dentro e fora deles. A partir desses retratos, marcados por processos violentos, a autora discute sua amplitude na discussão pública sobre a temática da privação de liberdade, e destaca esse movimento como uma forma de sensibilizar o público frente a questôes caras ao presente. As histórias de A.T, Cinderelo e Seu Zé, inscritas no presente através da memória, evidenciam uma "necessidade de mudança social", que emerge através dessas exposições. Assim, Borges destaca as possibilidades de discussáo sobre temáticas sensíveis a partir da trajetória de sujeitos marginalizados, que têm seus caminhos costurados por instituiçóes de controle.

O terceiro capítulo, "História Recente e processos participativos", de Letícia Bauer, propóe uma visão sobre as práticas museais no presente, e discute o papel social e político da instituição. Destaca-se sua atuaçáo frente ao Memorial do Rio Grande do 
Sul, do qual é diretora, e sua participação ativa na construção de exposições. A autora convida a refletir sobre o museu e os processos participativos realizados dentro dele, e articula a discussão sobre o papel dos museus no presente e a participação pública, a partir de construçóes realizadas com e para o público, problemáticas centrais no campo de História Pública.

No que tange práticas de História Pública, Sebástian Vargas Álvarez traz uma genealogia desse campo na Colômbia, analisando atividades desenvolvidas através do método de pesquisa-intervenção, que articula problemáticas sociais com propostas de acadêmicos e não acadêmicos. $\mathrm{O}$ objetivo do autor é reconhecer que essas atividades emergem enquanto antecedentes da História Pública, e estabelece cinco argumentos que aproximam essas experiências: pesquisa colaborativa, relato histórico para amplos públicos, processos de luta e resistências, apostas ficcionais e autogestáo. Por fim, investiga como essas práticas coletivas e participativas contribuíram para a visibilidade e incidência de discussão sobre o passado no debate público.

A intersecção entre memória e história é pano de fundo para o quinto capítulo, de Francisco das Chagas Santiago Junior, que aproxima os episódios de derrubada de monumentos em Charlottesville, nos Estados Unidos, e em Sáo Paulo. Traz à baila o ataque a uma História Pública específica, personificada nesses monumentos, e na atualização de debates sobre o passado no presente. Santiago Júnior observa os "passados não resolvidos" ao encarar o monumento como um artefato vivo, no qual as narrativas históricas que permitiram sua construção estão em constante debate no presente. Por conta disso, as agressões a diferentes monumentos se inscrevem em demandas sociais sobre sua manutenção ou retirada.

A violência perpassa a análise de Danny Gonzalo Monsálvez Araneda sobre a história recente chilena. Araneda repousa seu foco na importância da memória histórica sobre o período ditatorial, que reverbera na atualidade do país e atravessa o processo de construção de uma nova Constituição, marcada por intensos protestos pelas ruas de Santiago. Estabelece saltos entre o passado e o presente do Chile, repassando o papel da memória na construçáo da democracia recente, e analisa como a história se apresenta enquanto "ferramenta" para diagnosticar o presente. Assim, coloca a elaboraçáo do passado através da memória como uma das possibilidades para a história e a construção de um discurso crítico sobre o passado.

Um olhar sensível para o passado traumático é tema de Rogério Rosa Rodrigues no sétimo capítulo, que fecha a seção de artigos. Intitulado "A solidão das testemunhas", dialoga com Walter Benjamin e o "desafio de ouvir o clamor dos mortos". Reflete sobre o exercício de profissionais na memória e história de sujeitos do Contestado, confronto que opôs a República brasileira e os sertanejos do interior de Santa Catarina e Paraná, entre 1912 e 1916 . O autor encara uma elaborada narrativa histórica de fundo, que privilegiou durante décadas o olhar sobre agentes do exército que atuaram nas frentes de batalhas, e se remetiam às populaçôes sertanejas como sujeitos desviantes. Analisa 
o silenciamento das testemunhas do conflito, e evidencia propostas que valorizam a cultura cabocla da regiấo como exercícios de História Pública.

Os últimos capítulos trazem entrevistas com três historiadores que atuam nessa intersecção entre História Pública, História do Tempo Presente e História Oral. O objetivo é traçar um panorama sobre a área em diferentes espaços, e aproximar distintas práticas nesse cruzamento. Para isso, faz uma pequena biografia sobre suas carreiras e de seus interesses, além de explorar as possibilidades e desafios que a História Pública apresenta. Os entrevistados são Ana Maria Mauad, Eugenia Allier-Montaño e Serge Noiret.

Por toda a obra, a correnteza da memória nos empurra para diferentes passados. Nessa força, o papel de historiadores comprometidos em realizar elaboraçóes sobre esse desaguar se mostram crucias para enfrentar as agruras do presente. Através de uma narrativa crítica sobre o passado, História Pública e História do Tempo Presente aparece como uma obra que têm compromisso ético com a profissão e o fazer historiográfico, com as demandas do presente e, principalmente, com os diálogos possíveis com diferentes públicos, ávidos pelo contato com o passado. Além disso, evidencia caminhos teórico-metodológicos importantes para a História Oral, ao colocá-la como uma das práticas destacáveis no diálogo com e para o público. Assim, as três áreas abordadas se aproximam em suas potencialidades, e dialogam na elaboração de narrativas críticas sobre o passado.

Recebido em 13/07/2021.

Versão final reapresentada em 13/08/2021.

Aprovado em 31/08/2021.

Fonte de financiamento: Coordenação de Aperfeiçoamento de Pessoal de Nível Superior (Capes) - Bolsa.

Conflitos de interesse: nada a declarar. 